\title{
ZMIANA UMOWY SPÓŁKI KOMANDYTOWEJ A ZAKAZ ZAWIERANIA UMÓW „Z SAMYM SOBĄ” PRZEZ CZŁONKA ZARZĄDU SPÓŁKI Z OGRANICZONĄ ODPOWIEDZIALNOŚCIĄ
}

\begin{abstract}
Abstrakt: Przedmiotem analizy niniejszego artykułu jest zagadnienie dotyczące sposobu zmiany umowy spółki komandytowej, w której wspólnikami są spółka z ograniczoną odpowiedzialnością oraz członek zarządu tejże spółki kapitałowej. Wątpliwość, jaka pojawia się w przedstawionej sytuacji, związana jest z ustaleniem właściwej reprezentacji spółki kapitałowej przy dokonaniu zmiany umowy spółki komandytowej. Stosownie do art. 210 k.s.h. w umowach oraz sporach między spółką z ograniczoną odpowiedzialnością a członkiem jej zarządu wyłączona jest możliwość reprezentacji spółki przez zarząd. Przepisy kodeksu spółek handlowych nie regulują sposobu dokonania zmiany umowy spółki komandytowej; nie określają zatem, czy zmiana ta następuje w drodze umowy zmieniającej, czy też w drodze uchwały wspólników. Niezależnie od sposobu rozstrzygnięcia tej kwestii nie ulega wątpliwości, że przepis art. 210 k.s.h. obejmuje swą hipotezą nie tylko zawarcie umowy pomiędzy spółką z ograniczoną odpowiedzialnością a członkiem zarządu, lecz także inne czynności prawne związane z tą umową, w szczególności jej zmianę. W związku z tym, jeśli przyjmiemy, że zmiana umowy spółki komandytowej może być dokonana zarówno w trybie umownym, jak też w drodze uchwały wspólników, to konsekwentnie należy stwierdzić, iż niezależnie od przyjętego sposobu zmiany umowy spółki komandytowej — w przedstawionym stanie faktycznym — wyłączona jest możliwość reprezentacji spółki z ograniczoną odpowiedzialnością przez jej zarząd.
\end{abstract}

Słowa kluczowe: spółki prawa handlowego, zmiana umowy spółki komandytowej, reprezentacja spółki z ograniczoną odpowiedzialnością na podstawie art. 210 k.s.h.

I. Spółka komandytowa jako jedna z postaci osobowych spółek handlowych podlega przepisom prawnym odnoszącym się stricte do spółki komandytowej (tytuł II, dział III Spółka komandytowa), przepisom ogólnym dotyczącym wszystkich spółek osobowych (tytuł I, dział II Spółki osobowe), a przez odesłanie zawarte w art. 103 § 1 i 2 kodeksu spółek handlowych ${ }^{1}$ znajdują do niej odpowied-

${ }^{1}$ Ustawa z dnia 15 września 2000 roku — Kodeks spółek handlowych, tekst jedn. Dz.U. z 2019 r. poz. 505 ze zm. (dalej: k.s.h.). 
nie zastosowanie także przepisy o spółce jawnej (tytuł II, dział I Spółka jawna). W kwestii zmiany umowy spółki komandytowej mamy jedynie wprowadzony do kodeksu spółek handlowych ustawą z dnia 28 listopada 2014 roku$^{2}$ przepis art. $106^{1}$ k.s.h., który jednoznacznie określa sposób dokonania zmiany umowy spółki zawartej przy wykorzystaniu normatywnego wzorca umowy. W myśl § 4 tego artykułu umowa spółki komandytowej zawartej przy wykorzystaniu wzorca umowy może być także zmieniona $\mathrm{w}$ zakresie postanowień zmiennych umowy przy wykorzystaniu wzorca uchwały zmieniającej umowę spółki udostępnionego w systemie teleinformatycznym. Dodatkowo przepis art. $110 \S 2$ k.s.h. stanowi, że wszelkie zmiany danych, które — zgodnie z $\S 1$ tego artykułu — podlegają wpisowi do rejestru, powinny być zgłoszone sądowi rejestrowemu. Nie jest jednak przez ustawodawcę przesądzone, czy skutki dokonanych zmian umowy spółki, analogicznie jak powstanie samej spółki komandytowej (art. $109 \S 1$ k.s.h.), następują z chwilą wpisu do rejestru.

Wśród przepisów dotyczących spółki komandytowej, mających charakter uregulowań zarówno ogólnych, jak i szczególnych, nie ma odpowiednika art. 255 oraz art. 430 k.s.h., które - w odniesieniu do spółek kapitałowych — stanowią, że zmiana umowy (statutu) spółki wymaga uchwały wspólników (walnego zgromadzenia) i wpisu do rejestru. Na podstawie wskazanych przepisów prawnych można sformułować dwa niebudzące wątpliwości wnioski. Po pierwsze, zmiana umowy (statutu) spółki kapitałowej następuje uchwałą. Po drugie, wpisanie dokonanej zmiany umowy (statutu) spółki do rejestru ma charakter konstytutywny.

W odniesieniu do spółki komandytowej poza sporem pozostaje jedynie kwestia formy dokonania zmiany umowy spółki. Jeśli umowa spółki została zawarta przy wykorzystaniu normatywnego wzorca umowy, wówczas jej zmiana następuje w wyniku uchwały, dla której § 4 w związku z $§ 2$ art. $106^{1}$ k.s.h. wymaga zachowania formy elektronicznej, czyli opatrzenia uchwały kwalifikowanym podpisem elektronicznym, podpisem zaufanym albo podpisem osobistym. Jeśli natomiast umowa spółki komandytowej została zawarta w formie tradycyjnej, czyli w formie aktu notarialnego (art. 106 k.s.h.), to wprawdzie przepisy kodeksu spółek handlowych bezpośrednio nie normują kwestii formy dokonania jej zmiany, jednak sprawa ta nie należy do dyskusyjnych. Na podstawie odesłania zawartego w art. 2 k.s.h. należy zastosować przepisy kodeksu cywilnego ${ }^{3}$, a wśród nich art. $77 \S 1$ k.c., który stanowi, że uzupełnienie lub zmiana umowy wymaga zachowania takiej formy, jaką ustawa lub strony przewidziały w celu jej zawarcia ${ }^{4}$.

2 Dz.U. z 2015 r. poz. 4.

3 Ustawa z dnia 23 kwietnia 1964 roku - Kodeks cywilny, tekst jedn. Dz.U. z 2019 r. poz. 1145 ze zm. (dalej: k.c.).

4 Więcej zob. Z. Radwański, Z. Kuniewicz, Forma czynności prawnej, [w:] System Prawa Prywatnego, t. 2. Prawo cywilne - czesść ogólna, red. Z. Radwański, A. Olejniczak, Warszawa 2019, s. 216-218. 
Pewne wątpliwości może budzić sprawa sposobu zmiany umowy spółki komandytowej, która nie została zawarta z wykorzystaniem normatywnego wzorca umowy. Przepis art. 9 k.s.h. znajdujący się wśród przepisów ogólnych dotyczących spółek osobowych stwierdza jedynie, że zmiana postanowień umowy spółki wymaga zgody wszystkich wspólników, chyba że umowa stanowi inaczej. Gdy wspólnicy odstępują od wymogu uzyskania zgody wszystkich wspólników na zmianę umowy spółki, wówczas sprawa sposobu dokonania takiej zmiany staje się przesądzona. Następuje ona w drodze uchwały, która zapada odpowiednią, określoną w umowie spółki, większością głosów. Taki sposób zmiany umowy spółki był też akceptowany w piśmiennictwie prawniczym na tle kodeksu handlowego ${ }^{5}$. Przepis art. 78 k.h. do zmiany umowy spółki jawnej wymagał w $\S 1$ zgody wszystkich wspólników, jednocześnie w $§ 2$ stanowiąc, że nieważne są postanowienia umowy spółki, według których może być dokonana bez zgody wszystkich wspólników istotna jej zmiana. $Z$ treści tego przepisu wypływał wniosek, że jeżeli umowa spółki tak stanowiła, to zmiana nieistotnych jej postanowień mogła być dokonana niejednomyślnie. Jednocześnie w piśmiennictwie prawniczym przyjmowano, chociaż bez głębszych analiz, uchwałodawczy sposób dokonania zmiany umowy spółki jawnej. Zygmunt Fenichel pisał, że tylko postanowienia umowy dotyczące zmian istotnych bez zgody wszystkich wspólników są nieważne, w związ$\mathrm{ku} \mathrm{z}$ tym ,jeśli na podstawie takiego nieważnego postanowienia u chwalo no [wyr. - Z.K.] zmianę, to odnośna zmiana, jako nieważna, nie wywołuje skutków

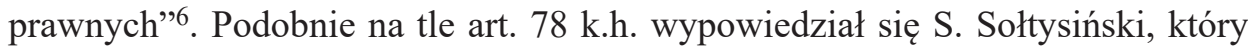
w odniesieniu do formy zmiany umowy spółki jawnej stwierdził, że „można ją więc zmienić w drodze ustnej u ch wa ły [wyr. - Z.K.]"'7. Trafność wyrażonych twierdzeń nie budziła wątpliwości, gdyż art. 77 k.h. stanowił, iż umowa spółki jawnej powinna być zawarta na piśmie.

II. Teza, że niewymagalność zgody wszystkich wspólników na zmianę umowy spółki przesądza o uchwałodawczym trybie dokonania jej zmiany, znajduje uzasadnienie w założeniach ogólnych, na których opiera się konstrukcja prawna oraz funkcjonowanie spółek handlowych. W kontekście przyjętych założeń podstawową kategorią jest pojęcie czynności prawnej, a w szczególności pojęcie umowy. Znajduje to wyraz w art. 3 k.s.h., który zawiera definicję spółki handlowej i odnosi się do wszystkich spółek osobowych i kapitałowych ${ }^{8}$ : „Przez umowę spółki handlowej wspólnicy albo akcjonariusze zobowiązują się dążyć do osią-

${ }^{5}$ Rozporządzenie Prezydenta Rzeczypospolitej z dnia 27 czerwca 1934 roku — Kodeks handlowy, Dz.U. z 1934 r. Nr 57, poz. 502 ze zm. (dalej: k.h.).

6 Z. Fenichel, [w:] T. Dziurzyński, Z. Fenichel, M. Honzatko, Kodeks handlowy z komentarzem i skorowidzem, Łódź 1994, s. 83.

7 S. Sołtysiński, [w:] S. Sołtysiński, A. Szajkowski, J. Szwaja, Kodeks handlowy. Komentarz, t. 1, Warszawa 1994, s. 521; por. też A. Wiśniewski, Prawo o spótkach. Podręcznik praktyczny, t. 1. Wiadomości ogólne. Spótki osobowe, Warszawa 1992, s. 108.

8 Por. T. Siemiątkowski, R. Potrzeszcz, [w:] Komentarz do kodeksu spótek handlowych. Spótki osobowe, red. T. Siemiątkowski, R. Potrzeszcz, Warszawa 2001, s. 33-34; A. Kidyba, Kodeks spółek 
gniecia wspólnego celu przez wniesienie wkładu oraz, jeżeli umowa albo statut spółki tak stanowi, przez współdziałanie w inny, określony sposób”.

Niejednokrotnie w przepisach kodeksu spółek handlowych ustawodawca posługuje się pojęciem uchwały będącej sposobem wyrażenia woli przez członków kolegialnego organu spółki kapitałowej albo przez wspólników osobowej spółki handlowej (zob. art. 39, 40, 42, $201 \S 5,208 \S 4,210 \S 1,222 \S 1$ k.s.h. itp.). Wedle przyjętej i powszechnie akceptowanej w nauce prawa cywilnego klasyfikacji czynności prawnych uchwały stanowią odrębną od umów postać czynności prawnych. Wskazując differentia specifica uchwał, podkreśla się, że w przeciwieństwie do umów nie obowiązuje tu zasada zgodnych oświadczeń woli uczestników tej czynności prawnej ${ }^{9}$. Na marginesie warto jedynie dodać, że nie wszystkie uchwały są czynnościami prawnymi; kwalifikację taką mają jedynie te uchwały, które zmierzają do wywołania skutków prawnych.

$\mathrm{Z}$ całą pewnością walor czynności prawnej przysługuje natomiast uchwale o zmianie umowy spółki. Brak jednoznacznego określenia przez ustawodawcę sposobu zmiany umowy osobowej spółki handlowej (uwaga ta nie dotyczy zmiany statutu spółki komandytowo-akcyjnej) może rodzić wątpliwości związane z ustaleniem prawidłowej reprezentacji podmiotów, które dokonują tej czynności prawnej. Podstawowy problem, jaki się tu pojawia, wyraża pytanie, czy wybór określonego sposobu zmiany umowy spółki osobowej przesądza o sposobie reprezentacji wspólnika, gdy jednym z nich jest osoba, wobec której obowiązuje zakaz dokonywania czynności prawnych „z samym sobą”.

III. Problem taki wyłonił się na tle spółki komandytowej i stał się kanwą rozważań Sądu Najwyższego w uchwale z dnia 7 września 2018 roku (III CZP $42 / 18)^{10}$. W stanie faktycznym rozpoznawanej sprawy komplementariuszem spółki komandytowej była spółka z ograniczoną odpowiedzialnością (dalej: spółka z o.o.), a w roli jednego z komandytariuszy tej spółki występowała osoba pełniąca funkcję członka zarządu w tejże spółce kapitałowej. Z ustaleń stanu faktycznego nie wynika, czy wspomniane osoby zawarły umowę spółki komandytowej (tak zwaną umowę pierwotną), czy też później uzyskały członkostwo w spółce, to jest już na etapie jej funkcjonowania. Kwestia ta nie jest jednak istotna, ponieważ przedmiotem badania nie jest ocena prawidłowości zawarcia umowy spółki, lecz ocena prawidłowości jej zmiany. $Z$ tego względu ważne jest, że w charakterze wspólników spółki komandytowej, którzy mają dokonać zmiany jej umowy, występują spółka z o.o. oraz członek zarządu tej spółki.

handlowych, t. 1. Komentarz do art. 1-300 k.s.h., Warszawa 2015, s. 31-33; J. Strzępka, E. Zielińska, [w:] Kodeks spótek handlowych. Komentarz, red. J. Strzępka, Warszawa 2015, s. 18-19.

9 Por. A. Wolter, J. Ignatowicz, K. Stefaniuk, Prawo cywilne. Zarys części ogólnej, Warszawa 1996, s. 246; Z. Radwański, A. Olejniczak, Prawo cywilne - część ogólna, Warszawa 2017, s. 229. W sprawie tak zwanej zasady majoryzacji przy podejmowaniu uchwał zob. A. Koch, Podważanie uchwat zgromadzeń spótek kapitałowych, Warszawa 2011, s. $1 \mathrm{n}$.

10 OSNC 2019, nr 6, poz. 64. 
W związku z potrzebą dokonania zmiany umowy spółki komandytowej wspólnicy podjęli uchwałę notarialnie zaprotokołowaną, wprowadzając do umowy stosowne zmiany. Na posiedzeniu wspólników spółki komandytowej spółka z o.o. była reprezentowana przez pełnomocnika, który został ustanowiony uchwałą zgromadzenia wspólników, podjętą w trybie art. 210 § 1 k.s.h. Spółka z o.o. jako komplementariusz uznała, że zachodzi potrzeba ustanowienia pełnomocnika, albowiem jednym ze wspólników w spółce komandytowej jest członek zarządu spółki z o.o. Sąd rejonowy odmówił jednak wpisu do rejestru zmiany umowy spółki, gdyż stwierdził, że przy podjęciu uchwały o zmianie umowy spółki komandytowej spółka z o.o. jako komplementariusz była wadliwie reprezentowana. Pełnomocnik tej spółki, który został powołany na podstawie art. $210 \S 1$ k.s.h., zdaniem sądu pierwszej instancji przekroczył zakres przysługującego mu umocowania. W ocenie sądu rejonowego głosowanie w sprawie zmiany umowy spółki osobowej, w której status wspólnika przysługuje spółce z o.o. oraz członkowi jej zarządu, nie jest objęte hipotezą art. $210 \S 1$ k.s.h. Udział pełnomocnika powołanego na podstawie tego przepisu prowadzi do bezwzględnej nieważności uchwały. Co istotne, sąd rejonowy dostrzegł potrzebę reprezentacji spółki z o.o. przez pełnomocnika ustanowionego na podstawie art. $210 \S 1$ k.s.h., ale tylko w przypadku zawarcia umowy spółki osobowej. W ocenie sądu rejonowego w następstwie wpisania spółki do rejestru umowa spółki traci swój charakter czysto obligacyjny, a uzyskuje obligacyjno-organizacyjny. Ponadto sąd pierwszej instancji podkreślił, że zmiana umowy spółki po jej wpisie do rejestru, następuje w trybie uchwały. Przedstawione przesłanki zdaniem sądu rejonowego uzasadniają, że zmiany umowy spółki komandytowej nie są objęte zakresem zastosowania art. $210 \S 1$ k.s.h.

Jednoznacznego stanowiska w omawianej kwestii nie zajął sąd okręgowy, chociaż przyjął on w swych rozważaniach ten kierunek rozumowania, który zaproponował sąd pierwszej instancji. Otóż sąd okręgowy założył dwa możliwe sposoby zmiany umowy spółki komandytowej i od przyjęcia określonego wariantu uzależnił konieczność stosowania przepisu art. $210 \S 1$ k.s.h. Zgodnie z pierwszym założeniem do zmiany umowy spółki dochodzi w podobny sposób, jak przy umowach prawa cywilnego. W świetle tego ujęcia zmiana umowy kreuje relacje między wspólnikami, dlatego następuje ona w drodze umowy zawartej przez wspólników. Natomiast według drugiej koncepcji zmiana umowy spółki komandytowej następuje w drodze uchwały podjętej przez wspólników. Zmiana umowy już istniejącej spółki — jak argumentuje sąd okręgowy — nie jest zmianą umowy obligacyjnej, „lecz zmianą dokonywaną przez wspólników w stosunku do spółki jako odrębnego podmiotu prawa".

Konsekwencją przyjęcia stanowiska zakładającego uchwałodawczy sposób zmiany umowy spółki jest wyłączenie konieczności stosowania mechanizmu ochrony spółki z o.o. określonego w art. $210 \S 1$ k.s.h. Uzasadniając ten pogląd, sąd okręgowy wskazał, że wykonywanie przez spółkę z o.o. prawa głosu przy zmianie umowy spółki komandytowej, nawet gdy wspólnikiem w tej spółce jest 
także członek zarządu, nie można utożsamiać z zawarciem umowy z członkiem zarządu. Nie znajduje zatem uzasadnienia stosowanie zasad reprezentacji spółki określonych we wskazanym art. $210 \S 1$ k.s.h.

IV. Przedstawione przez sądy powszechne propozycje rozwiązania problemu dotyczącego reprezentacji spółki z o.o. będącej oprócz członka jej zarządu wspólnikiem w spółce komandytowej skłaniają do polemicznej refleksji. Jak można zauważyć, prowadzone rozważania koncentrują się na analizie art. 210 § 1 k.s.h. Dlatego też należy przybliżyć podstawowe, niebudzące wątpliwości wnioski płynące $\mathrm{z}$ wykładni przywołanego przepisu, podkreślając jednocześnie cel tego unormowania.

Otóż zgodnie z art. 210 § 1 k.s.h. „w umowie między spółką a członkiem zarządu oraz w sporze z nim spółkę reprezentuje rada nadzorcza lub pełnomocnik powołany uchwałą zgromadzenia wspólników". Wywodzący się z cytowanego przepisu zakaz reprezentowania spółki przez zarząd ma szerszy zakres aniżeli wynikałoby to z formuły zakazu dokonywania czynności prawnych „z samym sobą”; nie odnosi się on jedynie do sytuacji, w której po obu stronach umowy występują te same osoby. W świetle art. $210 \S 1$ k.s.h. żaden z członków zarządu nie może reprezentować spółki, jeśli umowa jest zawierana między spółką a którymkolwiek członkiem zarządu.

Imperatywny charakter omawianego uregulowania nie budzi wątpliwości, jak też bezsporne jest, że art. $210 \S 1$ k.s.h., jako przepis o charakterze szczególnym, wymaga ścisłej wykładni. Należy przy tym podkreślić, że reprezentacja spółki będzie wadliwa zarówno wtedy, gdy mimo zakazu z art. $210 \S 1$ k.s.h. spółka będzie reprezentowana przez zarząd, jak i gdy na skutek błędnej interpretacji tego przepisu uznamy, że zachodzą przesłanki jego zastosowania. Należy przy tym odrzucić sugestię M. Allerhanda, wypowiedzianą jeszcze na gruncie art. 203 k.h. (odpowiednikiem tego przepisu jest art. 210 k.s.h.), który twierdził, że umowa zawarta z członkiem zarządu nie jest nieważna, chociaż zarząd nie powinien był jej dokonać ${ }^{11}$.

Jeszcze w ostatniej dekadzie ubiegłego wieku kwestią sporną pozostawała sprawa przedmiotowego zakresu zastosowania obowiązującego wówczas art. 203 k.h. ${ }^{12}$, a obecnie art. 210 k.s.h. Zagadnieniem tym niejednokrotnie zajmował się Sąd Najwyższy i obecnie, zarówno w judykaturze, jak i w doktrynie, osiągnięto w tej kwestii zgodność poglądów. Należy zatem podkreślić, że występujące w art. 210 k.s.h. wyrażenie „w umowie między spółką a członkiem zarządu” nie przewiduje żadnych przedmiotowych ograniczeń, które limitowałyby zakres jego

11 M. Allerhand, Kodeks handlowy. Spótka z ograniczonq odpowiedzialnościa. Komentarz, t. 2, Bielsko-Biała 1991, s. 54-55; zob. też Z. Kuniewicz, O kontrowersjach związanych z reprezentacja spótek kapitałowych na podstawie art. 203 i 374 kodeksu handlowego, „Przegląd Sądowy” 1996, nr 11-12, s. 67.

12 Por. wyrok Sądu Najwyższego z dnia 23 marca 1999 roku, II CKN 24/98, OSNC 1999, nr 11, poz. 187. 
zastosowania, odnosząc ten przepis jedynie do określonego rodzaju umów. Uzasadniony jest zatem wniosek, że omawiany przepis dotyczy wszystkich umów zawieranych między spółką a członkiem zarządu ${ }^{13}$.

Przyjęcie tak szerokiego zakresu zastosowania art. $210 \S 1$ k.s.h. uzasadnione jest celem tego przepisu. Powszechnie wskazuje się, że uregulowanie to ma służyć ochronie interesów spółki i jej wspólników w przypadku konfliktu interesów, który może powstać, gdy członek zarządu zawiera umowę „z samym sobą”, a więc gdy po obu stronach umowy występują te same osoby. Dodatkowo należy podkreślić, że nie jest konieczne, aby sprzeczność interesów rzeczywiście występowała; wystarczy możliwość wystąpienia kolizji indywidulanych interesów członków zarządu ${ }^{14}$.

V. Mając na względzie przytoczone wyjaśnienia, należy spojrzeć na problem sposobu zmiany umowy spółki komandytowej, w której wspólnikami są spółka z o.o. oraz członek zarządu tej spółki. Główną rolę przy wyjaśnieniu omawianej kwestii odgrywa wspomniany wcześniej art. 9 k.s.h., który do zmiany umowy spółki osobowej przewiduje wymóg zgody wszystkich wspólników, chyba że umowa spółki stanowi inaczej, przy czym konieczność uzyskania jednomyślności wspólników przy zmianie umowy spółki nie przesądza jeszcze o tym, że zmiana ta ma charakter umowny bądź uchwałodawczy. Skoro zatem ustawodawca nie rozstrzyga jednoznacznie tej kwestii, to należy podzielić pogląd wyrażony przez Sąd Najwyższy w uzasadnieniu uchwały z dnia 7 września 2018 roku, że zasadnicze znaczenie trzeba przypisać ustaleniu, czy uzyskany został konsensus wszystkich wspólników, który jest wymagany do zmiany umowy spółki. W świetle tego stwierdzenia kwestią drugorzędną pozostaje natomiast, czy tę zgodę wspólnicy wyrazili w umowie zmieniającej umowę spółki, czy też została ona objęta notarialnie zaprotokołowaną uchwałą wspólników. W obu przypadkach, przy zachowaniu właściwej formy dokonania tych czynności, należy uznać, że spełniony został warunek prawny z art. 9 k.s.h., przewidziany odnośnie do zmiany umowy spółki.

Wyrażając opinię, że w spółkach osobowych istnieje alternatywny (umowny lub uchwałodawczy) tryb zmiany umowy spółki, należy odpowiedzieć na pytanie, czy wybór określonego trybu ma wpływ na sposób reprezentacji wspólników przeprowadzających tę zmianę. W szczególności należy wyjaśnić, czy z przyję-

13 Por. wyrok Sądu Najwyższego z dnia 18 sierpnia 2005 roku, V CK 103/05, LEX nr 653638; wyrok Sądu Najwyższego z dnia 18 sierpnia 2005 roku, V CK 104/05, LEX nr 358805; wyrok Sądu Najwyższego z dnia 28 czerwca 2007 roku, IV CSK 106/07, LEX nr 955036; postanowienie Sądu Najwyższego z dnia 11 marca 2010 roku, IV CSK 413/09, LEX nr 677902; A. Kidyba, op. cit., s. 991; J. Strzępka, E. Zielińska, op. cit., s. 531-532; Z. Kuniewicz, M. Futrzyńska-Mielcarzewicz, Glosa do uchwały Sądu Najwyższego z 22 października 2009 r., III CZP 63/09, „Przegląd Sądowy” 2011, nr 11, s. 113 n.; Z. Kuniewicz, S. Czepita, Glosa do wyroku Sądu Najwyższego z 15 czerwca 2012 r., II CSK 217/11, OSP 2013, z. 9, poz. 94.

14 Por. Z. Kuniewicz, Glosa do uchwaty Sadu Najwyższego z 17 grudnia 2015 r., III CZP 91/15, OSP 2018, z. 6, poz. 57 i powołane tam w przyp. 4 orzecznictwo sądowe. 
tego trybu zmiany umowy spółki wypływa wniosek o konieczności stosowania art. $210 \S 1$ k.s.h.

Na przedstawione pytanie należy udzielić zdecydowanie negatywnej odpowiedzi. Przede wszystkim trzeba podkreślić, że kodeks spółek handlowych nie określa jasno, w jakim trybie powinna być dokonana zmiana umowy spółki komandytowej. W tej sytuacji przyjęcie stanowiska, według którego do trybu umownego stosujemy art. $210 \S 1$ k.s.h., do trybu zaś uchwałodawczego nie stosujemy tego przepisu, oznaczałoby, że same zainteresowane podmioty decydowałyby o tym, czy zakaz reprezentacji z art. $210 \S 1$ k.s.h. będzie respektowany. W ostateczności to sam członek zarządu spółki z o.o., decydując o uchwałodawczym trybie zmiany umowy spółki komandytowej, przesądzałby o tym, że mógłby on reprezentować i spółkę, i siebie przy dokonaniu tej zmiany.

W świetle tych uwag wyraźnie widać, że proponowane rozwiązanie nie może zostać zaakceptowane, ponieważ byłoby ono ewidentnie sprzeczne z celem, który ma realizować zakaz reprezentacji spółki wyrażony w art. $210 \S 1$ k.s.h. Rozwiązanie takie nie znajduje także uzasadnienia w wykładni językowej omawianego przepisu. Przez kodeksowe wyrażenie „w umowie między spółką a członkiem zarządu" należy rozumieć wszystkie czynności prawne związane z taką umową, a więc nie tylko jej zawarcie, ale też zmianę, odstąpienie od umowy, wypowiedzenie, rozwiązanie umowy za zgodą stron itp. W cytowanej formule chodzi zatem o wszelkie czynności prawne związane z umową, a więc również te czynności, które nie są czynnościami umownymi ${ }^{15}$. Do kręgu takich czynności z pewnością należy zmiana umowy spółki niezależnie od tego, czy jest ona dokonywana w drodze umowy, czy też w drodze uchwały. Trafna jest zatem teza uchwały Sądu Najwyższego z dnia 7 września 2018 roku (III CZP 42/18): „Jeżeli członek zarządu spółki z ograniczoną odpowiedzialnością jest wraz z tą spółką wspólnikiem spółki komandytowej, do wyrażenia przez spółkę z ograniczoną odpowiedzialnością zgody na zmianę umowy spółki komandytowej - wymaganej na podstawie art. 9 k.s.h. — ma zastosowanie art. $210 \S 1$ k.s.h.”. Podzielić należy również opinię Sądu Najwyższego zawartą w uzasadnieniu tej uchwały, że nawet jeśliby art. 210 $\S 1$ k.s.h. stanowił, iż przewidziany w nim sposób reprezentacji spółki z o.o. obowiązuje ,przy zawarciu umowy”, to przy takim sformułowaniu przepisu należałoby go stosować także przy zmianie umowy lub jej rozwiązaniu za porozumieniem stron.

Ochrona interesów spółki z o.o., która jest celem analizowanego art. $210 \S 1$ k.s.h., byłaby iluzoryczna, gdyby przyjąć, że przepis ten znajduje zastosowanie do zawarcia umowy, ale nie stosuje się go do zmiany umowy spółki. Wyrazem dowolnej interpretacji omawianego przepisu byłoby natomiast twierdzenie, że sto-

15 Por. Z. Kuniewicz, K. Malinowska-Woźniak, Reprezentacja spótki kapitałowej przy przyjęciu oświadczenia członka zarządu o rezygnacji, [w:] Kodeks spótek handlowych po 15 latach obowiązywania, red. J. Frąckowiak, Warszawa 2018, s. 551. 
sowanie art. $210 \S 1$ k.s.h. uzależnione jest od tego, w jakim trybie dokonuje się zmiany umowy spółki komandytowej. Trafnie zatem argumentuje Sąd Najwyższy w uzasadnieniu uchwały z dnia 7 września 2018 roku, że skoro zastosowanie reżimu ochronnego w zakresie reprezentacji spółki z o.o. aktualizuje się przy zawarciu umowy spółki (pierwotnej), to również reżim ten powinien być stosowany przy zmianie umowy spółki.

W celu jeszcze pełniejszego wyjaśnienia omawianego problemu należy dodać, że z punktu widzenia oceny prawidłowej reprezentacji wspólników przy zmianie umowy spółki komandytowej nie jest sprawą istotną, czy in casu umowa (pierwotna) spółki komandytowej została zawarta przez spółkę z o.o. oraz członka zarządu tej spółki. Przepis art. 210 § 1 k.s.h. znajdzie bowiem zastosowanie także wtedy, gdy wymienione podmioty uzyskają status wspólników spółki komandytowej już na etapie jej funkcjonowania.

\title{
AMENDING THE ARTICLES OF PARTNERSHIP OF A LIMITED PARTNERSHIP AND THE PROHIBITION OF EXECUTING CONTRACTS "WITH ONESELF” BY A MEMBER OF THE MANAGEMENT BOARD OF A LIMITED LIABILITY COMPANY
}

\begin{abstract}
Summary
The subject of analysis in this paper involves the question of the manner of amending the articles of partnership of a limited partnership whose partners include a limited liability company and a member of the management board of this company. A doubt arises in the presented situation concerning the establishment of appropriate representation of the capital company when making the said act in law involving the amendment of the articles of partnership of the limited partnership. Pursuant to Article 210(1) of the Commercial Companies Code, representation of a limited liability company in contracts and disputes between the company and a member of the management board is excluded. The provisions of the Commercial Companies Code do not prescribe the mode in which the articles of partnership of a limited partnership are to be amended; therefore, this amendment may be done by way of a contract or by way of a resolution of the partners. However, there is no doubt that the regulation of Article 210(1) CC covers with its hypothesis not only the execution of the contract between a limited liability company and a member of its management board, but also other acts in law associated with this contract, especially its amendment. Therefore, by allowing the possibility of amending the articles of partnership of a limited partnership both by way of a contract and a resolution of the partners, one should consistently assume that when making any of these acts in law - in the factual state presented above — the limited liability company's representation by the management board shall be excluded.
\end{abstract}

Keywords: commercial companies, amending the articles of partnership of a limited partnership, representation of a limited liability company under Article 210 of the Commercial Companies Code 


\section{BIBLIOGRAFIA}

Allerhand M., Kodeks handlowy. Spółka z ograniczona odpowiedzialnością. Komentarz, t. 2, Bielsko-Biała 1991.

Fenichel Z., [w:] Dziurzyński T., Fenichel Z., Honzatko M., Kodeks handlowy z komentarzem i skorowidzem, Łódź 1994.

Kidyba A., Kodeks spółek handlowych, t. 1. Komentarz do art. 1-300 k.s.h., Warszawa 2015.

Koch A., Podważanie uchwał zgromadzeń spółek kapitałowych, Warszawa 2011.

Kuniewicz Z., Glosa do uchwały Sądu Najwyższego z 17 grudnia 2015 r., III CZP 91/15, OSP 2018, z. 6 , poz. 57.

Kuniewicz Z., O kontrowersjach zwiąanych z reprezentacja spótek kapitałowych na podstawie art. 203 i 374 kodeksu handlowego, „Przegląd Sądowy” 1996, nr 11-12.

Kuniewicz Z., Czepita S., Glosa do wyroku Sadu Najwyższego z 15 czerwca 2012 r., II CSK 217/11, OSP 2013, z. 9, poz. 94.

Kuniewicz Z., Futrzyńska-Mielcarzewicz M., Glosa do uchwały Sądu Najwyższego z 22 października 2009 r., III CZP 63/09, „Przegląd Sądowy” 2011, nr 11.

Kuniewicz Z., Malinowska-Woźniak K., Reprezentacja spótki kapitałowej przy przyjęciu oświadczenia członka zarządu o rezygnacji, [w:] Kodeks spótek handlowych po 15 latach obowiazywania, red. J. Frąckowiak, Warszawa 2018.

Radwański Z., Kuniewicz Z., Forma czynności prawnej, [w:] System Prawa Prywatnego, t. 2. Prawo cywilne — część ogólna, red. Z. Radwański, A. Olejniczak, Warszawa 2019.

Radwański Z., Olejniczak A., Prawo cywilne - część ogólna, Warszawa 2017.

Siemiątkowski T., Potrzeszcz R., [w:] Komentarz do kodeksu spółek handlowych. Spółki osobowe, red. T. Siemiątkowski, R. Potrzeszcz, Warszawa 2001.

Sołtysiński S., [w:] Sołtysiński S., Szajkowski A., Szwaja J., Kodeks handlowy. Komentarz, t. 1, Warszawa 1994.

Strzępka J., Zielińska E., [w:] Kodeks spółek handlowych. Komentarz, red. J. Strzępka, Warszawa 2015.

Wiśniewski A., Prawo o spótkach. Podręcznik praktyczny, t. 1. Wiadomości ogólne. Spótki osobowe, Warszawa 1992.

Wolter A., Ignatowicz J., Stefaniuk K., Prawo cywilne. Zarys części ogólnej, Warszawa 1996. 